medRxiv preprint doi: https://doi.org/10.1101/2021.06.30.21259491; this version posted July 5, 2021. The copyright holder for this preprint (which was not certified by peer review) is the author/funder, who has granted medRxiv a license to display the preprint in perpetuity. This article is a US Government work. It is not subject to copyright under 17 USC 105 and is also made available for use under a CCO license.

\title{
Reduced COVID-19 Hospitalizations among New York City Residents Following Age- Based SARS-CoV-2 Vaccine Eligibility: Evidence from a Regression Discontinuity Design
}

Sharon K. Greene, PhD, MPH, ${ }^{\mathrm{a} *}$ Alison Levin-Rector, MPH, ${ }^{\mathrm{a}}$ Emily McGibbon, MPH, ${ }^{\mathrm{a}}$ Jennifer Baumgartner, MSPH, ${ }^{a}$ Katelynn Devinney, MPH, ${ }^{a}$ Alexandra Ternier, DPH, ${ }^{\mathrm{b}}$ Jessica Sell, $\mathrm{MPH},{ }^{\mathrm{a}}$ Rebecca Kahn, $\mathrm{PhD},{ }^{\mathrm{c}}$ Nishant Kishore, $\mathrm{MPH}^{\mathrm{c}}$

${ }^{\text {a }}$ Bureau of Communicable Disease, New York City Department of Health and Mental Hygiene, Long Island City, NY, USA

${ }^{\mathrm{b}}$ Bureau of Immunization, New York City Department of Health and Mental Hygiene, Long Island City, NY, USA

${ }^{c}$ Center for Communicable Disease Dynamics, Department of Epidemiology, Harvard T.H. Chan School of Public Health, Boston, MA, USA

*Corresponding author: sgreene4@health.nyc.gov

\begin{abstract}
Background: In clinical trials, several SARS-CoV-2 vaccines were shown to reduce risk of severe COVID-19 illness. Local, population-level, real-world evidence of vaccine effectiveness is accumulating. We assessed vaccine effectiveness for community-dwelling New York City (NYC) residents using a quasi-experimental, regression discontinuity design, leveraging a period (January 12-March 9, 2021) when $\geq 65$-year-olds were vaccine-eligible but younger persons, excluding essential workers, were not.
\end{abstract}

Methods: We constructed segmented, negative binomial regression models of age-specific COVID-19 hospitalization rates among 45-84-year-old NYC residents during a post-vaccination 
medRxiv preprint doi: https://doi.org/10.1101/2021.06.30.21259491; this version posted July 5, 2021. The copyright holder for this preprint (which was not certified by peer review) is the author/funder, who has granted medRxiv a license to display the preprint in perpetuity.

This article is a US Government work. It is not subject to copyright under 17 USC 105 and is also made available for use under a CCO license.

program implementation period (February 21-April 17, 2021), with a discontinuity at age 65 years. The relationship between age and hospitalization rates in an unvaccinated population was incorporated using a pre-implementation period (December 20, 2020-February 13, 2021). We calculated the rate ratio (RR) and $95 \%$ confidence interval $(\mathrm{CI})$ for the interaction between implementation period (pre or post) and age-based eligibility (45-64 or 65-84 years). Analyses were stratified by race/ethnicity and borough of residence. Similar analyses were conducted for COVID-19 deaths.

Results: Hospitalization rates among 65-84-year-olds decreased from pre- to postimplementation periods (RR 0.85, 95\% CI: 0.74-0.97), controlling for trends among 45-64-yearolds. Accordingly, an estimated 721 (95\% CI: 126-1,241) hospitalizations were averted. Residents just above the eligibility threshold (65-66-year-olds) had lower hospitalization rates than those below (63-64-year-olds). Racial/ethnic groups and boroughs with higher vaccine coverage generally experienced greater reductions in RR point estimates. Uncertainty was greater for the decrease in COVID-19 death rates (RR 0.85, 95\% CI: 0.66-1.10).

Conclusion: The vaccination program in NYC reduced COVID-19 hospitalizations among the initially age-eligible $\geq 65$-year-old population by approximately $15 \%$. The real-world evidence of vaccine effectiveness makes it more imperative to improve vaccine access and uptake to reduce inequities in COVID-19 outcomes.

\section{Keywords}

Vaccines, SARS-CoV-2, Surveillance, COVID-19, Public Health, Epidemiology 
medRxiv preprint doi: https://doi.org/10.1101/2021.06.30.21259491; this version posted July 5, 2021. The copyright holder for this preprint (which was not certified by peer review) is the author/funder, who has granted medRxiv a license to display the preprint in perpetuity.

This article is a US Government work. It is not subject to copyright under 17 USC 105 and is also made available for use under a CCO license.

\section{Introduction}

The SARS-CoV-2 vaccines authorized and recommended for emergency use in the United States were demonstrated in randomized clinical trials to reduce risk of severe COVID-19 illness [1-3]. Post-authorization, several studies have demonstrated real-world evidence of SARS-CoV-2 vaccine effectiveness in various settings, such as among skilled nursing facility residents and essential workers $[4,5]$, or at the national level [6, 7]. Local, population-level evidence of effectiveness can support public messaging to promote the importance of vaccination [8].

In New York City (NYC), guidelines for vaccine eligibility were established by the Office of the Governor of New York State. When vaccinations began on December 14, 2020 [9], eligibility was initially restricted to health care workers and residents and staff of long-term care facilities. Eligibility expanded to $\geq 75$-year-olds in the general population and essential workers (workers in education, public safety, and public transit, and first responders) on January 11, 2021 [10], to $\geq 65$-year-olds on January $12[11]$, to $\geq 60$-year-olds and additional categories of publicfacing essential workers on March 10 [12], to $\geq 50$-year-olds and individuals with comorbidities and underlying conditions on March 23 [13], to $\geq 30$-year-olds on March 30 [14], to $\geq 16$-yearolds on April 6 [14], and to $\geq 12$-year-olds on May 12 [15]. Screeners at vaccination sites verified age-based eligibility by requiring proof of age, such as a driver's license, IDNYC (a free municipal identification card for NYC residents), birth certificate, passport, permanent resident card, certificate of naturalization or citizenship, or life insurance policy or marriage certificate with birthdate [16]. Notably, vaccine eligibility for $\geq 65$-year-olds as of mid-January coincided with the second peak of COVID-19 hospitalizations in NYC [17], such that the vaccination program was established concurrently with a waning epidemic period. 
medRxiv preprint doi: https://doi.org/10.1101/2021.06.30.21259491; this version posted July 5, 2021. The copyright holder for this preprint (which was not certified by peer review) is the author/funder, who has granted medRxiv a license to display the preprint in perpetuity. This article is a US Government work. It is not subject to copyright under 17 USC 105 and is also made available for use under a CCO license.

Vaccinees and non-vaccinees are likely systematically different in ways that are difficult to observe (e.g., adherence to social distancing recommendations and presence of underlying conditions) yet influence their probability of SARS-CoV-2 infection and testing and COVID-19 hospitalization and death [18]. Cross-sectional studies comparing outcome rates among vaccinated and unvaccinated populations are susceptible to confounding due to population differences arising from volunteer selection bias, healthy vaccinee effects, and frailty bias [19].

The NYC Department of Health and Mental Hygiene (DOHMH) sought to assess evidence of population-level vaccine effectiveness in NYC, citywide and stratified by subpopulations with different vaccination coverage. We used a quasi-experimental observational study design to leverage an 8-week period (January 12-March 9, 2021) when community residents at an age threshold of $\geq 65$-years were vaccine-eligible but younger persons (excluding essential workers) were not.

\section{Methods}

\subsection{COVID-19 hospitalization and death data}

Confirmed and probable cases of COVID-19 [20] among NYC residents are reported to NYC DOHMH through electronic laboratory reporting, and hospitalizations and deaths for these patients are ascertained by routinely importing and matching data from supplemental systems, as previously described [21]. COVID-19 hospitalizations were defined as NYC residents admitted within +/- 14 days of the first date of specimen collection that tested positive for SARS-CoV-2 by a molecular or antigen test; or if not laboratory-positive but a symptomatic contact of a confirmed or probable case, then admitted within +/- 14 days of illness onset. Hospitalizations with missing admission date $(\mathrm{n}=940,3.3 \%)$ were omitted from analysis. COVID-19 deaths 
medRxiv preprint doi: https://doi.org/10.1101/2021.06.30.21259491; this version posted July 5, 2021. The copyright holder for this preprint (which was not certified by peer review) is the author/funder, who has granted medRxiv a license to display the preprint in perpetuity.

This article is a US Government work. It is not subject to copyright under 17 USC 105 and is also made available for use under a CCO license.

were defined as NYC residents who had a positive molecular test and (a) the cause-of-death on the death certificate was COVID-19 or similar, or b) COVID-19 was not a cause-of-death on the death certificate but the patient died within 60 days of a positive molecular test, and the death was not due to external causes such as injury ("confirmed deaths"); or the cause-of-death on the death certificate was COVID-19 or similar, but a positive molecular test was not reported ("probable deaths") [21]. Patient age was calculated as of January 12, 2021, not as of hospitalization or death date.

Two categories of patients were excluded from analysis. First, given low hospitalization and death rates [22], patients $<45$ years-old as of January 12, 2021 were excluded from the comparator for trends among vaccine-eligible $\geq 65$-year-olds. Patients $\geq 85$ years-old were also excluded for sparsity, such that the study population was restricted to 45-84-year-olds, i.e., +/20 years around the vaccine eligibility threshold of age 65 years. Second, patients residing in congregate settings (e.g., long-term care or correctional facilities) were excluded because their vaccine eligibility timing was different from community residents and less dependent on age. Such patients were identified by geocoding the residential address at time of report and matching to facility lists.

\subsection{Vaccination and population denominator data}

The cumulative percentage of NYC residents having received at least the first dose of a SARS-CoV-2 vaccine, by vaccination date and age at first dose, was obtained from the NYC DOHMH Citywide Immunization Registry [23], as reported by immunizing facilities. Singleyear of age population estimates for 2019 for the five NYC boroughs (equivalent to counties) were downloaded from the National Center for Health Statistics [24]. 
medRxiv preprint doi: https://doi.org/10.1101/2021.06.30.21259491; this version posted July 5, 2021. The copyright holder for this preprint (which was not certified by peer review) is the author/funder, who has granted medRxiv a license to display the preprint in perpetuity.

This article is a US Government work. It is not subject to copyright under 17 USC 105 and is also made available for use under a CCO license.

\subsection{Program implementation timing}

We assumed that population-level vaccine effects on hospitalizations would not be apparent until 4 weeks after age-based eligibility was established. Within that period, we accounted for 1 week to begin substantial vaccination uptake in the newly eligible population, an additional 2 weeks after receipt of the first dose for a partially protective effect from vaccination, and an additional 1 week for hospitalizations to occur among those infected. Following the same logic, we assumed that vaccine effects on deaths would not be apparent until 6 weeks after agebased eligibility was established, additionally accounting for an average lag of approximately 2 weeks between COVID-19 hospitalization and death.

We defined pre- and post-vaccination program implementation periods of 8 weeks each, defining weeks as Sundays-Saturdays. We chose 8 weeks to correspond with the duration of the period (January 12-March 9, 2021) when only $\geq 65$-year-olds had age-based eligibility. For the primary analysis for hospitalizations, we defined the pre-implementation period as December 20, 2020-February 13, 2021, i.e., an 8-week period ending 4 weeks after $\geq 65$-year-olds became eligible on Jan. 12. Imposing a 1-week washout period, we defined the post-implementation period as February 21-April 17, 2021. For the primary analysis for deaths, we defined the preimplementation period as January 3-February 27, 2021, i.e., an 8-week period ending 6 weeks after $\geq 65$-year-olds became eligible on Jan. 12. Imposing a 2-week washout period to account for additional ambiguity in the timing of vaccine effects, we defined the post-implementation period as March 14-May 8, 2021. Data were frozen as of June 28, 2021, capturing hospitalizations ascertained within 72 days and deaths ascertained within 51 days after the ends of the post- 
medRxiv preprint doi: https://doi.org/10.1101/2021.06.30.21259491; this version posted July 5, 2021. The copyright holder for this preprint (which was not certified by peer review) is the author/funder, who has granted medRxiv a license to display the preprint in perpetuity.

This article is a US Government work. It is not subject to copyright under 17 USC 105 and is also made available for use under a CCO license.

implementation periods for the primary analysis. In sensitivity analyses, we shifted implementation period definitions and imposed washout periods of different lengths.

\subsection{Regression discontinuity design}

We constructed segmented, negative binomial regression models of the age-specific hospitalization (and death) rates during the post-vaccination program implementation period, with a discontinuity at age 65 years. We used pre-implementation period data to incorporate the observed relationship between age and hospitalization rates in an unvaccinated population. We expected the overall hospitalization rate in the post-implementation period to be lower due to the waning stage of the epidemic, but for trends across age to persist. We specified the model as a standard regression discontinuity design with a control group and indexed and centered the values for age and their corresponding interaction terms for appropriate interpretations of regression coefficients of interest (Appendix A) [25]. The analytic dataset for the hospitalizations primary analysis is provided for reproducibility (Appendix B). Analyses were conducted using PROC GENMOD in SAS Version 9.4 (SAS Institute, Cary, NC). This work was deemed public health surveillance that is non-research by the NYC DOHMH Institutional Review Board.

The key parameter of interest was $\beta_{6}$, the interaction term between vaccine program implementation period (pre or post) and age-based eligibility (45-64 or 65-84 years), representing the adjusted difference in log rates (intercept change) for 65-year-olds following age-based eligibility [26-29] (Appendix A). We exponentiated this parameter estimate and 95\% confidence interval $(\mathrm{CI})$ to obtain the rate ratio (RR) of interest and $95 \% \mathrm{CI}$.

\subsection{Estimating hospitalizations and deaths averted}


medRxiv preprint doi: https://doi.org/10.1101/2021.06.30.21259491; this version posted July 5, 2021. The copyright holder for this preprint (which was not certified by peer review) is the author/funder, who has granted medRxiv a license to display the preprint in perpetuity.

This article is a US Government work. It is not subject to copyright under 17 USC 105 and is also made available for use under a CCO license.

We estimated hospitalizations and deaths among 65-84-year-olds during the postimplementation period under the counterfactual scenario in which there were no effects of vaccination. That is, we estimated hospitalizations and deaths in this group had they experienced the same intercept and slope change from the pre- to post-implementation periods as the 45-64year-olds but experienced no discontinuity due to the implementation of the age-based vaccination policy. As above, let $\beta_{6}$ equal the parameter of a fitted negative binomial model describing the log difference of hospitalization rates between pre- and post-implementation periods among 65-84-year-olds, controlling for the decrease in hospitalizations in the postimplementation period due to the waning epidemic. Therefore, $e^{\beta 6}$ is the rate ratio of this parameter.

Let $Y_{65-84}$ equal the observed hospitalization rate among 65-84-year-olds in the postimplementation period and $N_{65-84}$ equal the total population of 65-84-year-olds in NYC. Therefore, the counterfactual scenario in which there was no change in the hospitalization rate between 65-84-year-olds in the pre- and post-implementation periods, controlling for the decrease in hospitalizations in the post-implementation period is:

$$
\dot{Y}_{65-84}=Y_{65-84} *\left(1+\left(1-e^{\beta 6}\right)\right)
$$

and the expected number of hospitalizations in the counterfactual is:

$$
\dot{H}_{65-84}=N_{65-84} * \dot{Y}_{65-84}
$$

while the observed number of hospitalizations is:

$$
H_{65-84}=N_{65-84} * Y_{65-84}
$$

Finally, assuming $\beta_{6}$ is negative, the number of averted hospitalizations is defined as:

$$
A_{65-84}=\dot{H}_{65-84}-H_{65-84}
$$

Therefore, the final equation of averted hospitalizations is: 
medRxiv preprint doi: https://doi.org/10.1101/2021.06.30.21259491; this version posted July 5, 2021. The copyright holder for this preprint (which was not certified by peer review) is the author/funder, who has granted medRxiv a license to display the preprint in perpetuity. This article is a US Government work. It is not subject to copyright under 17 USC 105 and is also made available for use under a CCO license.

$$
A_{65-84}=\left[N_{65-84} * Y_{65-84} *\left(1+\left(1-e^{\beta 6}\right)\right)\right]-\left[N_{65-84} * Y_{65-84}\right]
$$

Similarly, for the $95 \% \mathrm{CI}$, we replaced $\beta_{6}$ with the upper and lower limits of the parameter's CI. The same approach was used to calculate averted deaths.

\subsection{Stratified analyses and negative controls}

To assess heterogeneity of findings for hospitalizations across subpopulations with different vaccination rates, stratified analyses were conducted by race/ethnicity and borough of residence, where non-missing. Stratified analyses were not conducted for deaths given sparsity, nor for sub-borough areas because borough was the smallest geographic resolution available with population denominators by single year of age [24].

We used negative controls to assess whether findings for citywide COVID-19 hospitalizations might be attributable to unknown sources of error [30]. If the vaccination program were effective, then these methods should demonstrate reduced COVID-19 hospitalization rates when applied at the $\geq 65$ years age threshold during the period around vaccine program implementation, but null effects when applied to a different age threshold or to earlier periods when no SARS-CoV-2 vaccines were available.

First, we modified our primary analysis by redefining the age groups from 45-64 and 6584 (corresponding to the true age threshold of $\geq 65$ years) to $30-49$ and $50-79$ (corresponding to a false age threshold of $\geq 50$ years). Second, we modified the primary analysis by shifting the 16week study period with 1-week washout period to four negative control points earlier in the epidemic based on trends in citywide hospitalizations [17], defining the start of the postimplementation period as May 10, 2020 (when hospitalizations were at a similar magnitude and waning during the first epidemic wave), August 16, 2020 (when hospitalizations were low 
medRxiv preprint doi: https://doi.org/10.1101/2021.06.30.21259491; this version posted July 5, 2021. The copyright holder for this preprint (which was not certified by peer review) is the author/funder, who has granted medRxiv a license to display the preprint in perpetuity. This article is a US Government work. It is not subject to copyright under 17 USC 105 and is also made available for use under a CCO license.

between epidemic waves), December 20, 2020 (when hospitalizations were waxing during the second wave), and January 24, 2021 (when hospitalizations were steady during the second wave prior to widespread community vaccine availability).

\section{Results}

\subsection{Trends in vaccination coverage and COVID-19 hospitalizations}

As of January 16, 2021 (the end of the week age-based eligibility began for $\geq 65$-yearolds), the cumulative percentage of 65-84-year-old NYC residents having received at least the first dose of a SARS-CoV-2 vaccine was 6.5\% (Figure 1). By March 9 (the last day prior to $\geq 60$ year-olds also becoming vaccine-eligible), $47.6 \%$ of $65-84$-year-olds were vaccinated, compared with only $22.2 \%$ of 45-64-year-olds. Vaccination coverage of 65-84-year-olds by March 9 varied widely by race/ethnicity, ranging from $26.2 \%$ of Black/African-American NYC residents to $45.9 \%$ of Asian/Pacific Islander NYC residents. Vaccination coverage of 65-84-year-olds as of March 20 (4 weeks before the end of the post-implementation period) was $55.8 \%$. During the second COVID-19 wave in NYC, the timing of peak hospitalizations was similar for younger (45-64) and older (65-84) age groups (Figure 1).

\subsection{Regression discontinuity design, primary analysis}

Among 2,027,014 45-64-year-old NYC residents, 5,563 COVID-19 hospitalizations occurred during the pre-implementation period and 4,977 occurred during the postimplementation period (Appendix B). Among 1,101,467 65-84-year-old NYC residents, the number of hospitalizations during pre- and post-implementation periods were 7,557 and 4,780, 
medRxiv preprint doi: https://doi.org/10.1101/2021.06.30.21259491; this version posted July 5, 2021. The copyright holder for this preprint (which was not certified by peer review) is the author/funder, who has granted medRxiv a license to display the preprint in perpetuity.

This article is a US Government work. It is not subject to copyright under 17 USC 105 and is also made available for use under a CCO license.

respectively. During the pre-implementation period, hospitalization rates increased with increasing age in years (Figure 2).

The hospitalization rate in the post-implementation period was lower across all ages when compared with the pre-implementation period, likely due to the waning epidemic. Even so, there was a significant negative intercept shift in the hospitalization rate of 65-84-year-olds in the post-implementation period, and 65- and 66-year-olds just above the age threshold for eligibility had lower hospitalization rates than 63- and 64-year-olds just below the threshold (Figure 2). Hospitalization rates among 65-84-year-olds during the post-implementation period decreased compared with the pre-implementation period (RR $0.85,95 \% \mathrm{CI}: 0.74-0.97, P=$ 0.02), controlling for the epidemic trend among 45-64-year-olds, a group without concurrent age-based vaccine eligibility (Table). As expected, the hospitalization rate increased with age in both pre- and post-implementation periods. The 3-way interaction between vaccine program implementation, age-based eligibility, and age in years was null, indicating that the trajectory of the hospitalization rate with increasing age did not differ before and after program implementation among 65-84-year-olds.

Thus, there was a $15.1 \%(95 \% \mathrm{CI}: 2.6 \%-26.0 \%)$ reduction in the hospitalization rate among 65-84-year-olds during the post-implementation period compared with the preimplementation period and accounting for the overall decrease in hospitalizations in the postimplementation period. This translates to an estimated 721 (95\% CI: 126-1,241) hospitalizations averted during the 8-week post-implementation period, which are causally attributable to the vaccination program as the only intervention to reduce COVID-19 illness implemented at the $\geq 65$-year-old threshold during this period. 
medRxiv preprint doi: https://doi.org/10.1101/2021.06.30.21259491; this version posted July 5, 2021. The copyright holder for this preprint (which was not certified by peer review) is the author/funder, who has granted medRxiv a license to display the preprint in perpetuity. This article is a US Government work. It is not subject to copyright under 17 USC 105 and is also made available for use under a CCO license.

In stratified analyses (Table), boroughs where residents had higher vaccination coverage generally had greater reductions in the hospitalization rate ratio point estimate, although only the citywide and Staten Island estimates were statistically significant at $\alpha=0.05$. The Bronx was an outlier, with no change in the hospitalization rate ratio (RR 1.02, 95\% CI: $0.82-1.27$ ).

Black/African American individuals had the lowest vaccination coverage as of March 9 and experienced the least reduction in hospitalization rates, although differences across race/ethnic groups were not statistically significant.

Citywide during the post-implementation period, the decrease in death rates among 6584-year-olds was of a similar magnitude as the decrease in hospitalization rates, but deaths were sparser so uncertainty around this estimate was wide (RR 0.85, 95\% CI: $0.66-1.10, P=0.22$ ) (Table).

\subsection{Sensitivity analyses and negative controls}

Findings were generally robust to program implementation period definitions. For hospitalizations, shifting the period and imposing washout periods of different lengths had minor effects on the rate ratio point estimates but influenced whether results were statistically significant. The effect for death rates was closer to the null in sensitivity analyses using earlier period definitions and further from the null using later definitions. The strongest reduction in death rates was observed when shifting the implementation period 2 weeks later and with a 1week washout period (RR 0.78, 95\% CI: 0.60-0.999, $P=0.05$ ). As expected, negative controls using a false age threshold or periods prior to vaccine availability yielded no reductions in COVID-19 hospitalization rates among the older age group (Table). 
medRxiv preprint doi: https://doi.org/10.1101/2021.06.30.21259491; this version posted July 5, 2021. The copyright holder for this preprint

(which was not certified by peer review) is the author/funder, who has granted medRxiv a license to display the preprint in perpetuity.

This article is a US Government work. It is not subject to copyright under 17 USC 105 and is also made available for use under a CCO license.

\section{Discussion}

The SARS-CoV-2 vaccination program in NYC reduced the COVID-19 hospitalization rate among the initially age-eligible population by approximately $15 \%$ and was responsible for approximately 721 averted hospitalizations during the 8 weeks following program implementation. These are remarkable reductions, especially with low vaccination coverage among 65-84-year-olds during the first 8 weeks of eligibility, when demand generally exceeded supply and the cumulative percentage having received at least the first dose increased from $6.5 \%$ to only $47.6 \%$. Our findings were robust to sensitivity analyses and negative controls.

With a regression discontinuity design, the main threat to validity would be other interventions or events to reduce COVID-19 hospitalizations that were implemented according to the same $\geq 65$-year-old threshold and at the same time. We are unaware of any other such interventions or events, so confounding is unlikely, supporting a causal interpretation of the results [31]. The vaccination program in NYC began when the epidemic was already waning. As a point of comparison, in nearby Massachusetts, age-based eligibility began for $\geq 75$-year-olds on February 1, 2021 [32], 1 month after the second wave of COVID-19 hospitalizations peaked in early January [33]. A strength of the regression discontinuity design (as opposed to, for example, an interrupted time series design) is avoiding the misattribution of reduced hospitalizations to vaccination as opposed to epidemic trends. Had we used time as the continuous running variable, the epidemic peak in the pre-implementation period would have complicated efforts to disentangle the vaccination program from other secular trends. While there was no discontinuity in hospitalizations over time (Fig. 1), there was a sharp discontinuity in hospitalizations by age at the vaccine eligibility threshold of 65-years-old (Fig. 2). 
medRxiv preprint doi: https://doi.org/10.1101/2021.06.30.21259491; this version posted July 5, 2021. The copyright holder for this preprint (which was not certified by peer review) is the author/funder, who has granted medRxiv a license to display the preprint in perpetuity. This article is a US Government work. It is not subject to copyright under 17 USC 105 and is also made available for use under a CCO license.

In stratified analyses, we observed suggestive but not statistically significant associations between increasing vaccination coverage and stronger reductions in hospitalization rate ratios. Residents of the Bronx and Brooklyn, as well as Black/African-American NYC residents, had lower vaccination coverage and appeared to experience the least reduction in COVID-19 hospitalization rates. Equitable vaccine access is urgently needed to reduce pronounced inequities in COVID-19 outcomes [34].

\section{Limitations}

The primary limitation is that our estimates of reduced COVID-19 hospitalizations in NYC attributable to the SARS-CoV-2 vaccination program are likely underestimates. The regression discontinuity design in this setting was "fuzzy" and akin to a randomized trial with imperfect adherence [35]. Vaccination coverage did not increase instantaneously following the January 12, 2021 eligibility date. Many individuals above the $\geq 65$ years age eligibility threshold were unvaccinated, while many essential workers $<65$ years-old became eligible concurrently [10] and were vaccinated. A small proportion of persons who were 64 years-old as of January 12, 2021 and vaccine-ineligible would have turned 65 years-old and vaccine-eligible during the postimplementation period. Any vaccination coverage among $<65$-year-olds (although beneficial for vaccine recipients through the direct effects of vaccination and those around them through indirect effects [19]) would have diluted differences between older and younger groups and biased estimates of vaccine effects for the older group toward the null. Slightly faster convergence in vaccination rates between older and younger groups might partially explain why the Bronx was an outlier in stratified analyses, with no change in the hospitalization rate ratio; a mass vaccination site at Yankee Stadium, restricted to eligible Bronx residents, opened on 
medRxiv preprint doi: https://doi.org/10.1101/2021.06.30.21259491; this version posted July 5, 2021. The copyright holder for this preprint

(which was not certified by peer review) is the author/funder, who has granted medRxiv a license to display the preprint in perpetuity.

This article is a US Government work. It is not subject to copyright under 17 USC 105 and is also made available for use under a CCO license.

February 5, 2021 [36], contributing to relatively quicker vaccine uptake in the Bronx among the younger age group. Similar mass vaccination sites were not opened in other boroughs until almost 3 weeks later on February 24 [37].

This study leveraged a brief, 8-week period during which age-based eligibility was restricted to $\geq 65$-year-olds, which was only a limited period for observing reductions in hospitalization and death rates overall and any heterogeneity across subpopulations with different vaccination coverage. These estimates could not be updated using the regression discontinuity design as vaccination coverage further increased or as age eligibility expanded to younger persons, given lack of an appropriate comparator. Additionally, vaccine effects on asymptomatic or mild infections could not be assessed because vaccinated patients could have been less likely to seek testing, so estimates based on reported cases could have been biased.

Findings from the regression discontinuity design would have been further strengthened with a negative control outcome $[30,38]$, i.e., demonstrating no reduction among $\geq 65$-year-olds post-vaccine program implementation in hospitalizations for a different cause also associated with age, such as myocardial infarctions. However, hospitalization data for COVID-19, but not for other causes, were ascertained through emergency response efforts to import and match data from supplemental systems [21]. Such an analysis could be explored in the future once comprehensive, all-payer hospitalization data for NYC residents become available from the Statewide Planning and Research Cooperative System (SPARCS) [39].

Finally, data included in this analysis were preliminary and subject to missing observations, missing values, and misclassification. Hospitalizations were incompletely ascertained via matching with external sources [21]. Additionally, a small proportion of hospitalizations classified as COVID-19-attributable might have been due to other causes (e.g., 
medRxiv preprint doi: https://doi.org/10.1101/2021.06.30.21259491; this version posted July 5, 2021. The copyright holder for this preprint (which was not certified by peer review) is the author/funder, who has granted medRxiv a license to display the preprint in perpetuity.

This article is a US Government work. It is not subject to copyright under 17 USC 105 and is also made available for use under a CCO license.

injuries) or were misclassified because DOHMH quality assurance processes might not have eliminated all patients who only had an encounter at an emergency department but were not admitted to a hospital. However, missing or misclassified hospitalizations would bias findings only if differential both by age and time, which is unlikely. Immunizations were incompletely ascertained for NYC residents who were vaccinated outside of New York State or by federal programs. Demographic data, notably for race/ethnicity, were incomplete for both hospitalizations and immunizations. Population denominators by single year of age were unavailable for small geographic areas or for disaggregated race/ethnic groups, limiting the ability to further examine inequities [40]. Furthermore, the denominators were vintage 2019 and did not account for any population changes between pre- and post-implementation periods or pandemic-related deaths and outmigration from NYC [41]; however, large-scale population changes during the brief period examined are unlikely, and the denominators yielded hospitalization rates with the expected positive association with increasing age during the preimplementation period (Figure 2).

\section{Conclusion}

We demonstrated real-world evidence of SARS-CoV-2 vaccination effectiveness in protecting NYC residents in the community setting from severe COVID-19 illness. The regression discontinuity design is valid for causal inference and is low-cost to implement as an ecological, observational study with no requirement to ascertain individual-level vaccination status. This design could be used by other local and state health departments to demonstrate vaccination effects in their own jurisdictions to support public and provider messaging about the importance of vaccination. Such an approach would complement other methods for evaluating 
medRxiv preprint doi: https://doi.org/10.1101/2021.06.30.21259491; this version posted July 5, 2021. The copyright holder for this preprint (which was not certified by peer review) is the author/funder, who has granted medRxiv a license to display the preprint in perpetuity.

This article is a US Government work. It is not subject to copyright under 17 USC 105 and is also made available for use under a CCO license.

real-world vaccine effectiveness, including mathematical model-based approaches for estimating outcomes averted [42, 43] and test-negative designs [44]. 
medRxiv preprint doi: https://doi.org/10.1101/2021.06.30.21259491; this version posted July 5, 2021. The copyright holder for this preprint (which was not certified by peer review) is the author/funder, who has granted medRxiv a license to display the preprint in perpetuity.

This article is a US Government work. It is not subject to copyright under 17 USC 105 and is also made available for use under a CCO license.

\section{Declaration of competing interest}

RK discloses consulting fees from Partners In Health. Otherwise, the authors declare that they have no known competing financial interests or personal relationships that could have appeared to influence the work reported in this paper.

\section{Acknowledgments}

The authors thank all NYC DOHMH staff serving in the Surveillance and Epidemiology Section and Vaccine Operations Center of the Incident Command System. We thank the Bureau of Vital Statistics for mortality data management, Iris Cheng for contributions to immunization data management, Dr. Jane Zucker for constructive manuscript review, and Dr. Annie Fine for contributions to conceptualization and data management oversight.

\section{Funding}

SKG was supported by the Public Health Emergency Preparedness Cooperative Agreement (grant No. NU90TP922035-02), funded by the US Centers for Disease Control and Prevention (CDC). ALR was supported by ELC CARES (grant No. NU50CK000517-01-09), funded by CDC. RK was supported by the U.S. National Cancer Institute Seronet cooperative agreement U01CA261277. This article's contents are solely the responsibility of the authors and do not necessarily represent the official views of CDC or the Department of Health and Human Services. The funders had no role in study design; data collection, analysis, or interpretation; writing of the article; or in the decision to submit the article for publication. 
medRxiv preprint doi: https://doi.org/10.1101/2021.06.30.21259491; this version posted July 5, 2021. The copyright holder for this preprint

(which was not certified by peer review) is the author/funder, who has granted medRxiv a license to display the preprint in perpetuity.

This article is a US Government work. It is not subject to copyright under 17 USC 105 and is also made available for use under a CCO license.

\section{References}

[1] Oliver SE, Gargano JW, Marin M, Wallace M, Curran KG, Chamberland M, et al. The Advisory Committee on Immunization Practices' interim recommendation for use of PfizerBioNTech COVID-19 Vaccine - United States, December 2020. MMWR Morb Mortal Wkly Rep 2020;69:1922-4. 10.15585/mmwr.mm6950e2.

[2] Oliver SE, Gargano JW, Marin M, Wallace M, Curran KG, Chamberland M, et al. The Advisory Committee on Immunization Practices' Interim recommendation for use of Moderna COVID-19 Vaccine - United States, December 2020. MMWR Morb Mortal Wkly Rep 2021;69:1653-6. 10.15585/mmwr.mm695152e1.

[3] Oliver SE, Gargano JW, Scobie H, Wallace M, Hadler SC, Leung J, et al. The Advisory Committee on Immunization Practices' interim recommendation for use of Janssen COVID19 Vaccine - United States, February 2021. MMWR Morb Mortal Wkly Rep 2021;70:32932. $10.15585 / \mathrm{mmwr} . \mathrm{mm} 7009 \mathrm{e} 4$.

[4] Thompson MG, Burgess JL, Naleway AL, Tyner HL, Yoon SK, Meece J, et al. Interim estimates of vaccine effectiveness of BNT162b2 and mRNA-1273 COVID-19 vaccines in preventing SARS-CoV-2 infection among health care personnel, first responders, and other essential and frontline workers - Eight U.S. Locations, December 2020-March 2021. MMWR Morb Mortal Wkly Rep 2021;70:495-500. 10.15585/mmwr.mm7013e3.

[5] Britton A, Jacobs Slifka KM, Edens C, Nanduri SA, Bart SM, Shang N, et al. Effectiveness of the Pfizer-BioNTech COVID-19 vaccine among residents of two skilled nursing facilities experiencing COVID-19 outbreaks - Connecticut, December 2020-February 2021. MMWR Morb Mortal Wkly Rep 2021;70:396-401. 10.15585/mmwr.mm7011e3.

[6] Haas EJ, Angulo FJ, McLaughlin JM, Anis E, Singer SR, Khan F, et al. Impact and effectiveness of mRNA BNT162b2 vaccine against SARS-CoV-2 infections and COVID-19 cases, hospitalisations, and deaths following a nationwide vaccination campaign in Israel: an observational study using national surveillance data. Lancet 2021. 10.1016/S01406736(21)00947-8.

[7] Haas EJ, McLaughlin JM, Khan F, Angulo FJ, Anis E, Lipsitch M, et al. Preprint: Infections, hospitalizations, and deaths averted via direct effects of the Pfizer-BioNTech BNT162b2 mRNA COVID-19 vaccine in a nationwide vaccination campaign, Israel (http://dx.doi.org/10.2139/ssrn.3845367, accessed May 21, 2021). 2021.

[8] Chokshi DA. [@NYCHealthCommr] April 14, 2021. Vaccines are lifesaving: The 7-day average rate of admission into hospitals for COVID-like illness among New Yorkers 65 and older has fallen by $51 \%$ since mid-January, compared to $29 \%$ for those under 65. [Tweet]. Twitter. https://twitter.com/NYCHealthCommr/status/1382327010324799490.

[9] Murthy BP, Sterrett N, Weller D, Zell E, Reynolds L, Toblin RL, et al. Disparities in COVID-19 vaccination coverage between urban and rural counties - United States, December 14, 2020-April 10, 2021. MMWR Morb Mortal Wkly Rep 2021;70:759-64. 10.15585/mmwr.mm7020e3. 
medRxiv preprint doi: https://doi.org/10.1101/2021.06.30.21259491; this version posted July 5, 2021. The copyright holder for this preprint

(which was not certified by peer review) is the author/funder, who has granted medRxiv a license to display the preprint in perpetuity.

This article is a US Government work. It is not subject to copyright under 17 USC 105 and is also made available for use under a CCO license.

[10] NYS Governor's Press Office. Governor Cuomo Announces Expanded Vaccination Network To Accelerate Distribution of COVID-19 Vaccine (https://www.governor.ny.gov/news/governor-cuomo-announces-expanded-vaccinationnetwork-accelerate-distribution-covid-19-vaccine), January 8, 2021.

[11] Feldman AE, Reisman N. New Yorkers 65 and over now eligible for COVID-19 vaccine, Cuomo announces (https://www.ny1.com/nyc/all-boroughs/news/2021/01/12/new-yorkers65-and-over-now-eligible-for-covid-19-vaccine--cuomo-announces, accessed May 2, 2021).

[12] NYS Governor's Press Office. Governor Cuomo Announces New Yorkers 60 Years of Age and Older and Additional Public Facing Essential Workers Will Be Eligible to Receive COVID-19 Vaccine (https://www.governor.ny.gov/news/governor-cuomo-announces-newyorkers-60-years-age-and-older-and-additional-public-facing), March 9, 2021.

[13] NYS Governor's Press Office. Governor Cuomo Announces New Yorkers 50 Years of Age and Older Will Be Eligible to Receive COVID-19 Vaccine (https://www.governor.ny.gov/news/governor-cuomo-announces-new-yorkers-50-years-ageand-older-will-be-eligible-receive-covid-19), March 22, 2021.

[14] NYS Governor's Press Office. Governor Cuomo Announces New Yorkers 30 Years of Age and Older Will Be Eligible to Receive COVID-19 Vaccine (https://www.governor.ny.gov/news/governor-cuomo-announces-new-yorkers-30-years-ageand-older-will-be-eligible-receive-covid-19), March 29, 2021.

[15] NYS Governor's Press Office. Governor Cuomo Accepts NYS Clinical Advisory Task Force Recommendation to Immediately Implement Expanded Use Authorization of the Pfizer COVID-19 Vaccine for 12 to 15 -Year-Olds (https://www.governor.ny.gov/news/governor-cuomo-accepts-nys-clinical-advisory-taskforce-recommendation-immediately-implement), May 12, 2021.

[16] NYC DOHMH. COVID-19: vaccination requirements; proof of age (https://www1.nyc.gov/site/doh/covid/covid-19-vaccine-eligibility.page). Accessed June 2, 2021.

[17] NYC DOHMH. COVID-19 data: Cases, hospitalizations and deaths; citywide hospitalizations by admission date (https://www1.nyc.gov/site/doh/covid/covid-19-datatrends.page\#epicurve). Accessed May 2, 2021.

[18] Hak E, Verheij TJ, Grobbee DE, Nichol KL, Hoes AW. Confounding by indication in nonexperimental evaluation of vaccine effectiveness: the example of prevention of influenza complications. J Epidemiol Community Health 2002;56:951-5. 10.1136/jech.56.12.951.

[19] Lopez Bernal JA, Andrews N, Amirthalingam G. The use of quasi-experimental designs for vaccine evaluation. Clin Infect Dis 2019;68:1769-76. 10.1093/cid/ciy906.

[20] CDC National Notifiable Diseases Surveillance System (NNDSS). Coronavirus Disease 2019 (COVID-19) 2020 Interim Case Definition, Approved August 5, 2020 (https://ndc.services.cdc.gov/case-definitions/coronavirus-disease-2019-2020-08-05/). 
medRxiv preprint doi: https://doi.org/10.1101/2021.06.30.21259491; this version posted July 5, 2021. The copyright holder for this preprint

(which was not certified by peer review) is the author/funder, who has granted medRxiv a license to display the preprint in perpetuity.

This article is a US Government work. It is not subject to copyright under 17 USC 105 and is also made available for use under a CCO license.

[21] Thompson CN, Baumgartner J, Pichardo C, Toro B, Li L, Arciuolo R, et al. COVID-19 Outbreak - New York City, February 29-June 1, 2020. MMWR Morb Mortal Wkly Rep 2020;69:1725-9. 10.15585/mmwr.mm6946a2.

[22] NYC DOHMH. COVID-19 data: Case, hospitalization and death rates; hospitalization and death rates by age (https://www1.nyc.gov/site/doh/covid/covid-19-data-totals.page\#rates). Accessed May 3, 2021.

[23] NYC DOHMH. Citywide Immunization Registry (CIR): COVID-19 vaccines (https://www1.nyc.gov/site/doh/providers/reporting-and-services/citywide-immunizationregistry-cir.page). Accessed June 7, 2021.

[24] National Center for Health Statistics. Vintage 2019 postcensal estimates of the resident population of the United States (April 1, 2010, July 1, 2010-July 1, 2019), by year, county, single-year of age $(0,1,2, . ., 85$ years and over $)$, bridged race, Hispanic origin, and sex. Prepared under a collaborative arrangement with the U.S. Census Bureau. Available from: /nchs/nvss/bridged_race.htm as of July 9, 2020, following release by the U.S. Census Bureau of the unbridged Vintage 2019 postcensal estimates by 5-year age group on June 25, 2020. 2020.

[25] Xiao H, Augusto O, Wagenaar BH. Reflection on modern methods: a common error in the segmented regression parameterization of interrupted time-series analyses. Int $\mathbf{J}$ Epidemiol 2020. 10.1093/ije/dyaa148.

[26] Vandenbroucke JP, le Cessie S. Commentary: regression discontinuity design: let's give it a try to evaluate medical and public health interventions. Epidemiology 2014;25:738-41. 10.1097/EDE.0000000000000145.

[27] Moscoe E, Bor J, Barnighausen T. Regression discontinuity designs are underutilized in medicine, epidemiology, and public health: a review of current and best practice. J Clin Epidemiol 2015;68:122-33. 10.1016/j.jclinepi.2014.06.021.

[28] Basta NE, Halloran ME. Evaluating the effectiveness of vaccines using a regression discontinuity design. Am J Epidemiol 2019;188:987-90. 10.1093/aje/kwz043.

[29] Anderson ML, Dobkin C, Gorry D. The effect of influenza vaccination for the elderly on hospitalization and mortality: an observational study with a regression discontinuity design. Ann Intern Med 2020;172:445-52. 10.7326/M19-3075.

[30] Lipsitch M, Tchetgen Tchetgen E, Cohen T. Negative controls: a tool for detecting confounding and bias in observational studies. Epidemiology 2010;21:383-8. 10.1097/EDE.0b013e3181d61eeb.

[31] Hernán MA. The c-word: scientific euphemisms do not improve causal inference from observational data. Am J Public Health 2018;108:616-9. 10.2105/AJPH.2018.304337. 
medRxiv preprint doi: https://doi.org/10.1101/2021.06.30.21259491; this version posted July 5, 2021. The copyright holder for this preprint

(which was not certified by peer review) is the author/funder, who has granted medRxiv a license to display the preprint in perpetuity.

This article is a US Government work. It is not subject to copyright under 17 USC 105 and is also made available for use under a CCO license.

[32] Commonwealth of Massachusetts. Massachusetts' COVID-19 vaccination phases (https://www.mass.gov/info-details/massachusetts-covid-19-vaccination-phases, accessed May 7, 2021).

[33] Commonwealth of Massachusetts. COVID-19 Interactive Data Dashboard (https://www.mass.gov/info-details/covid-19-response-reporting\#covid-19-interactive-datadashboard, accessed May 7, 2021).

[34] Ogedegbe G, Ravenell J, Adhikari S, Butler M, Cook T, Francois F, et al. Assessment of racial/ethnic disparities in hospitalization and mortality in patients with COVID-19 in New York City. JAMA Netw Open 2020;3:e2026881. 10.1001/jamanetworkopen.2020.26881.

[35] Bor J, Moscoe E, Mutevedzi P, Newell ML, Barnighausen T. Regression discontinuity designs in epidemiology: causal inference without randomized trials. Epidemiology 2014;25:729-37. 10.1097/EDE.0000000000000138.

[36] NYS Governor's Press Office. Governor Cuomo and Mayor de Blasio Announce Mass Vaccination Site at Yankee Stadium to Open Friday (https://www.governor.ny.gov/news/governor-cuomo-and-mayor-de-blasio-announce-massvaccination-site-yankee-stadium-open-friday), February 3, 2021.

[37] NYS Governor's Press Office. Governor Cuomo Announces Opening of State-FEMA Mass Vaccination Site at York College in Queens and Medgar Evers College in Brooklyn (https://www.governor.ny.gov/news/governor-cuomo-announces-opening-state-fema-massvaccination-site-york-college-queens-and), February 24, 2021.

[38] Carpenter C, Dobkin C. The minimum legal drinking age and public health. J Econ Perspect 2011;25:133-56. 10.1257/jep.25.2.133.

[39] New York State. Statewide Planning and Research Cooperative System (SPARCS) (https://www.health.ny.gov/statistics/sparcs/, accessed May 7, 2021).

[40] Clemens A, Garvey M. Structural racism and the coronavirus recession highlight why more and better U.S. data need to be widely disaggregated by race and ethnicity (https://equitablegrowth.org/structural-racism-and-the-coronavirus-recession-highlight-whymore-and-better-u-s-data-need-to-be-widely-disaggregated-by-race-and-ethnicity/, accessed May 15, 2021). Washington Center for Equitable Growth 2020.

[41] Quealy K. The richest neighborhoods emptied out most as coronavirus hit New York City (https://www.nytimes.com/interactive/2020/05/15/upshot/who-left-new-yorkcoronavirus.html). May 15, 2020. The New York Times.

[42] Tokars JI, Rolfes MA, Foppa IM, Reed C. An evaluation and update of methods for estimating the number of influenza cases averted by vaccination in the United States. Vaccine 2018;36:7331-7. 10.1016/j.vaccine.2018.10.026. 
medRxiv preprint doi: https://doi.org/10.1101/2021.06.30.21259491; this version posted July 5, 2021. The copyright holder for this preprint (which was not certified by peer review) is the author/funder, who has granted medRxiv a license to display the preprint in perpetuity. This article is a US Government work. It is not subject to copyright under 17 USC 105 and is also made available for use under a CCO license.

[43] Chung JR, Rolfes MA, Flannery B, Prasad P, O'Halloran A, Garg S, et al. Effects of influenza vaccination in the United States during the 2018-2019 influenza season. Clin Infect Dis 2020;71:e368-e76. 10.1093/cid/ciz1244.

[44] Darvishian M, Bijlsma MJ, Hak E, van den Heuvel ER. Effectiveness of seasonal influenza vaccine in community-dwelling elderly people: a meta-analysis of test-negative design casecontrol studies. Lancet Infect Dis 2014;14:1228-39. 10.1016/S1473-3099(14)70960-0. 
Table. Reductions in COVID-19 hospitalizations and deaths among 65-84-year-old New York City community residents following age-based SARS-CoV-2 vaccine eligibility.

\begin{tabular}{|c|c|c|c|c|c|c|c|c|c|}
\hline \multirow[b]{2}{*}{ Outcome } & \multirow[b]{2}{*}{ Stratum } & \multirow[b]{2}{*}{ Level } & \multicolumn{2}{|c|}{$\begin{array}{l}\text { Coverage for } \geq 1 \\
\text { dose of a SARS- } \\
\text { CoV-2 vaccine } \\
\text { administered by } \\
\text { Mar } 9,2021^{1}\end{array}$} & \multicolumn{3}{|c|}{$\begin{array}{l}\text { Rate ratio for outcome } \\
\text { among } 65-84 \text {-year-olds } \\
\text { post-vaccine program } \\
\text { implementation }\end{array}$} & \multicolumn{2}{|c|}{$\begin{array}{c}\text { Outcomes averted } \\
\text { among } 65-84 \text {-year- } \\
\text { olds } \\
\text { post-vaccine } \\
\text { program } \\
\text { implementation }\end{array}$} \\
\hline & & & $\begin{array}{l}\% \text { of } \\
65-84- \\
\text { year- } \\
\text { olds }\end{array}$ & $\begin{array}{c}\% \text { of } \\
45-64- \\
\text { year- } \\
\text { olds } \\
\end{array}$ & $\begin{array}{l}\text { Rate } \\
\text { ratio } \\
\left(e^{\beta 6}\right) \\
Z X_{y}\end{array}$ & $95 \% \mathrm{CI}$ & $\begin{array}{c}P- \\
\text { value }\end{array}$ & $\mathrm{N}$ & $95 \% \mathrm{CI}$ \\
\hline \multirow[t]{10}{*}{ Hospitalizations } & Primary analysis ${ }^{2}$ & Citywide & 47.6 & 22.2 & 0.85 & $0.74-0.97$ & 0.02 & 721 & $126-1,241$ \\
\hline & \multirow[t]{4}{*}{ Race/ethnicity ${ }^{3}$} & Asian/Pacific Islander & 45.9 & 20.6 & 0.80 & $0.59-1.09$ & 0.16 & 125 & $-55-258$ \\
\hline & & White & 44.9 & 20.6 & 0.79 & $0.61-1.01$ & 0.06 & 255 & $-11-463$ \\
\hline & & Hispanic/Latino $^{4}$ & 30.5 & 13.2 & 0.83 & $0.67-1.03$ & 0.09 & 210 & $-34-408$ \\
\hline & & $\begin{array}{l}\text { Black/African- } \\
\text { American }\end{array}$ & 26.2 & 12.8 & 0.95 & $0.79-1.16$ & 0.63 & 57 & $-196-266$ \\
\hline & \multirow[t]{5}{*}{ Borough } & Manhattan & 60.9 & 27.2 & 0.76 & $0.57-1.02$ & 0.07 & 151 & $-15-275$ \\
\hline & & Staten Island & 55.7 & 25.9 & 0.65 & $0.44-0.98$ & 0.04 & 88 & $5-143$ \\
\hline & & Queens & 46.1 & 22.1 & 0.79 & $0.63-1.01$ & 0.06 & 289 & $-8-523$ \\
\hline & & Bronx & 45.5 & 22.1 & 1.02 & $0.82-1.27$ & 0.86 & -17 & $-238-160$ \\
\hline & & Brooklyn & 38.7 & 18.2 & 0.88 & $0.73-1.06$ & 0.17 & 194 & $-89-430$ \\
\hline
\end{tabular}

${ }^{1}$ March 9, 2021 was the last date in New York State when only $\geq 65$-year-olds had age-based vaccine eligibility.

${ }^{2}$ For the primary analysis for hospitalizations, the pre-vaccine program implementation period was December 20, 2020-February 13, 2021, the 1-week washout period was February 14-20, 2021, and the post-vaccine program implementation period was February 21-April 17, 2021.

${ }^{3}$ Of 22,877 COVID-19 hospitalizations of NYC residents 45-84 years-old during the period in the primary analysis, $1,519(6.6 \%)$ were missing race/ethnicity and 706 (3.1\%) identified as other racial/ethnic categories (e.g., Native American/Alaska Native or multi-racial). Of 974,113 NYC residents 45-84 years-old with $\geq 1$ dose of a SARS-CoV-2 vaccine administered by Mar 9, 2021, 119,387 (12.3\%) were missing race/ethnicity and 106,292 (10.9\%) identified as other racial/ethnic categories.

${ }^{4}$ The Hispanic/Latino category included people of any race. 


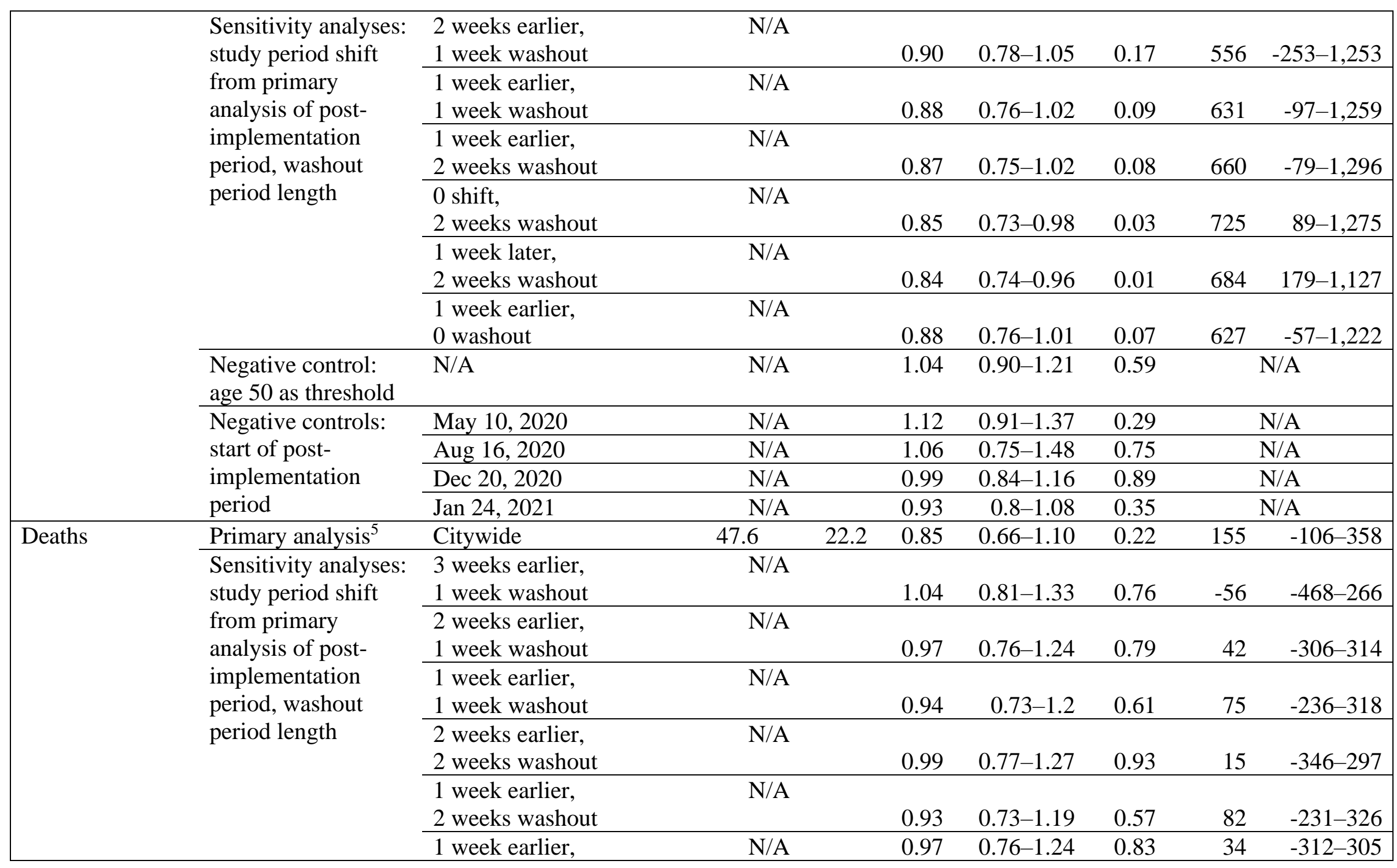

${ }^{5}$ For the primary analysis for deaths, the pre-vaccine program implementation period was January 3-February 27, 2021, the 2-week washout period was February 28-March 13, 2021, and the post-vaccine program implementation period was March 14-May 8, 2021. 


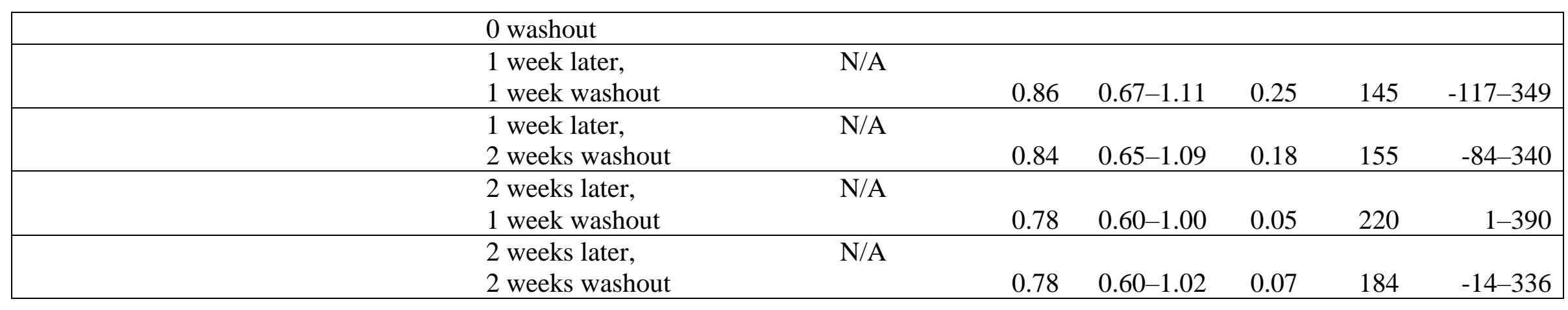


Figure 1. Weekly COVID-19 hospitalizations and cumulative vaccine coverage among 45-64 and 65-84-year-olds in relation to timing of age-based SARS-CoV-2 vaccine eligibility, New York City, December 13, 2020-April 17, 2021.

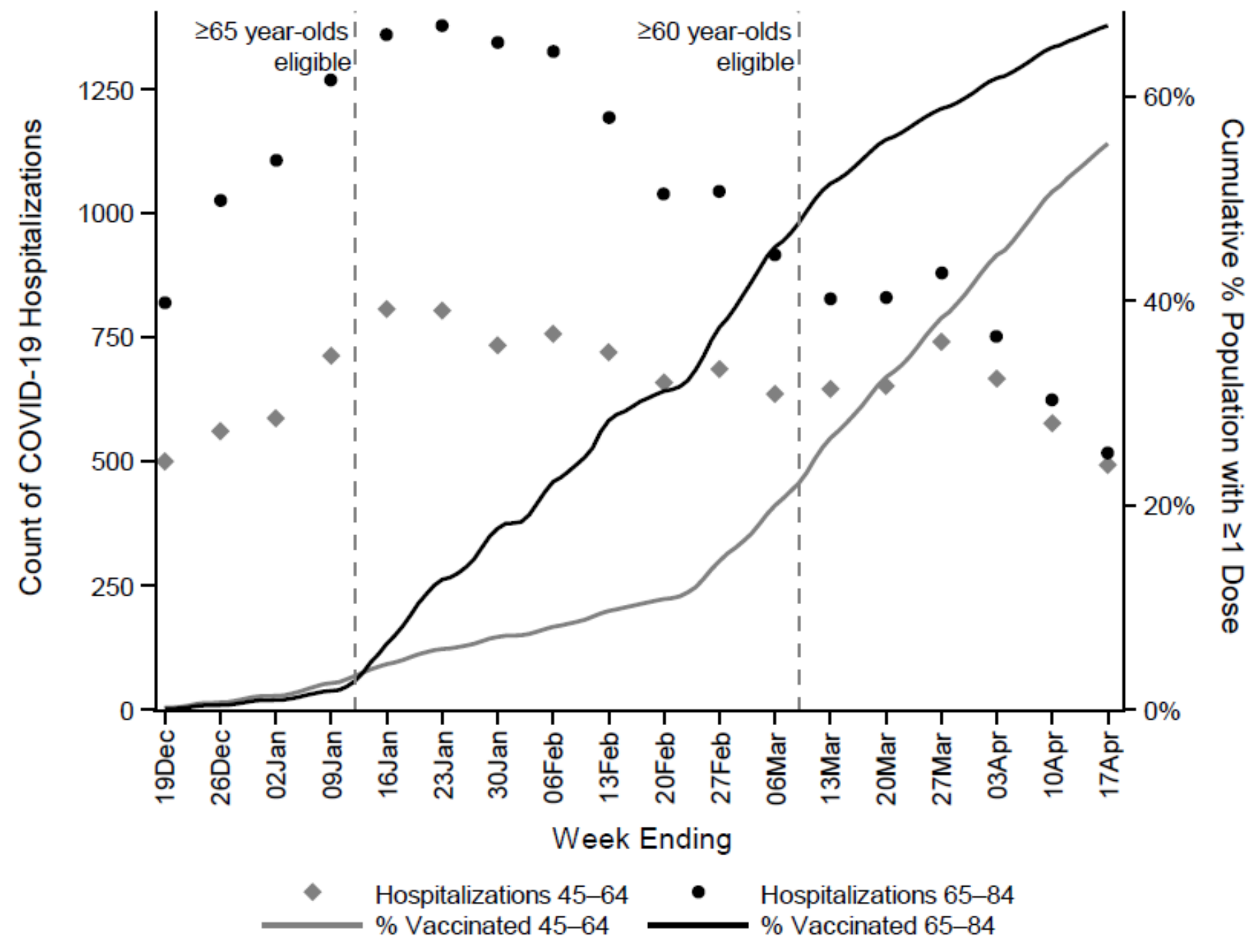


Figure 2. COVID-19 hospitalization rates among New York City residents by year of age during 8-week pre- (December 20, 2020-

Feb 13, 2021) and post- (February 21-April 17, 2021) implementation periods for the SARS-CoV-2 vaccine program.

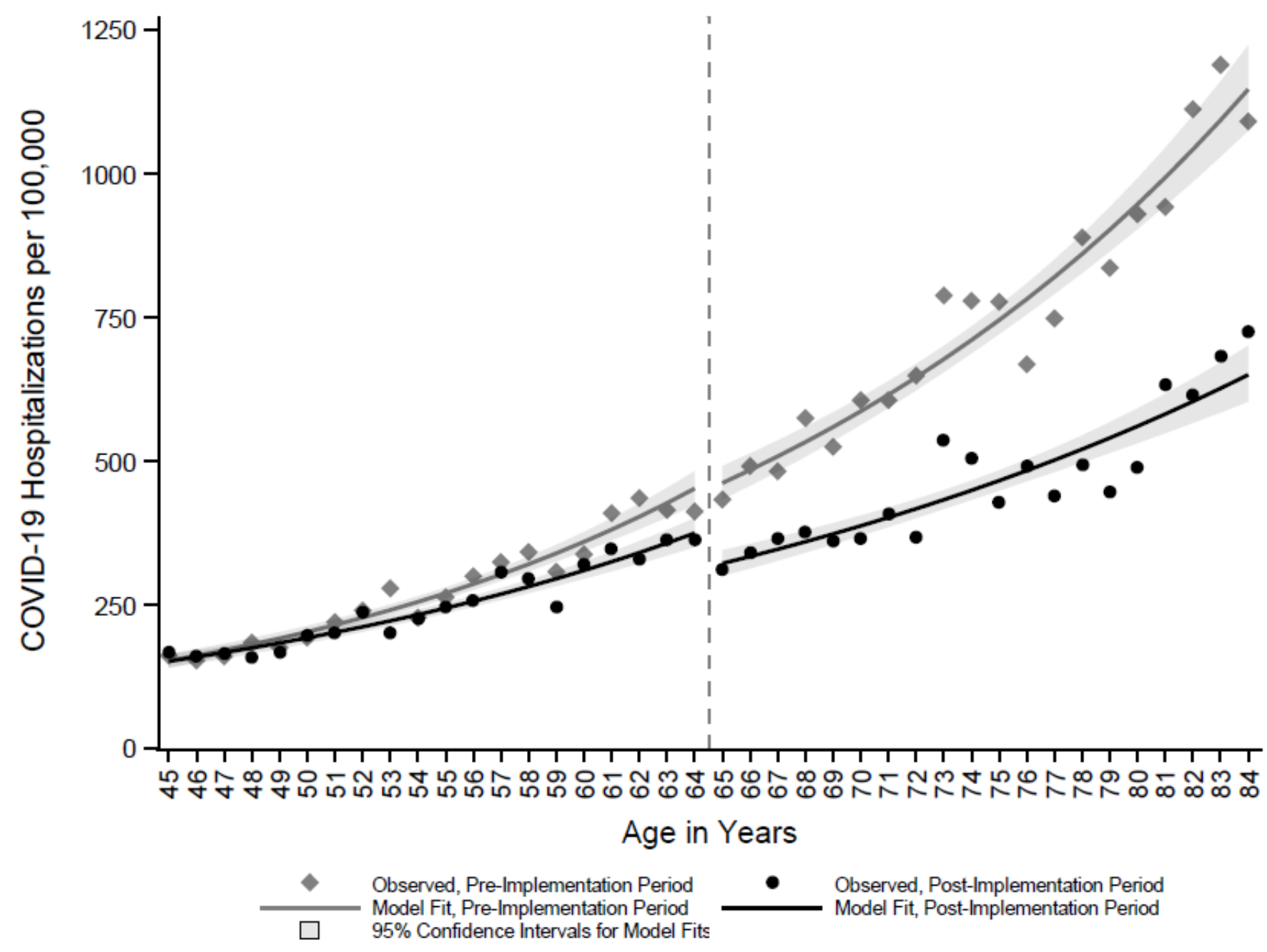


medRxiv preprint doi: https://doi.org/10.1101/2021.06.30.21259491; this version posted July 5, 2021. The copyright holder for this preprint

(which was not certified by peer review) is the author/funder, who has granted medRxiv a license to display the preprint in perpetuity.

This article is a US Government work. It is not subject to copyright under 17 USC 105 and is also made available for use under a CCO license.

Appendix A. Negative binomial regression model specification for controlled regression

discontinuity analysis.

$$
Y_{y}=\beta_{0}+\beta_{1} A+\beta_{2} X_{y}+\beta_{3} A X_{y}+\beta_{4} Z+\beta_{5} Z A+\beta_{6} Z X_{y}+\beta_{7} Z X_{y} A+\log (N)+\mathrm{e}_{\mathrm{t}} \text {, where: }
$$

$Y_{y}$ : outcome, i.e., count (or rate, with use of offset term) of hospitalizations (or deaths) measured at each year of age $y$

$\beta_{0}$ : intercept, i.e., level of outcome among 45 -year-olds prior to vaccine program implementation

$A$ : age in years as of Jan. 12, 2021, continuous starting with 45-year-olds (i.e., 0 if 45 years, then sequentially numbered, i.e., 1 if 46,2 if $47, \ldots 39$ if 84$). \beta_{1}$ is the slope, i.e., trajectory of the outcome with each increasing year of age until age 65 years prior to vaccine program implementation.

$\mathrm{X}_{y}$ : dummy variable representing vaccine program age-based eligibility (45-64-year-olds $=0$, $65-84$-year-olds $=1$ ). $\beta_{2}$ is the intercept for 65 -year-olds prior to vaccine program implementation.

$A X_{y}$ : interaction term between age in years and age-based eligibility ( 0 if age $\leq 65$, then sequentially numbered, i.e., 1 if 66,2 if $67, \ldots 19$ if 84$). \beta_{3}$ represents the change in slope or trajectory of the outcome for 65-84-year-olds relative to 45-64-year-olds prior to vaccine program implementation.

$Z$ : dummy variable representing vaccine program implementation (pre-implementation period $=$ 0 , post-implementation period $=1$ ). $\beta_{4}$ represents the difference in the level (intercept) of the outcome among 45-year-olds after vaccine program implementation.

$Z A$ : interaction term between vaccine program implementation and age ( 0 if pre-implementation period; else age indicator). $\beta$ 5 represents the difference in the trajectory (slope) of the outcome for 45-64-year-olds before and after program implementation.

$Z X_{y}$ : interaction term between vaccine program implementation and age-based eligibility ( 0 if 45-64 years-old or pre-implementation period; else 1 if 65-84y and post-implementation period). $\beta_{6}$ represents the difference before and after program implementation in the outcome level for 65-year-olds, i.e., immediately following age-based eligibility. This is the key result of interest.

$Z X_{y} A$ : 3-way interaction term between vaccine program implementation, age-based eligibility, and age in years ( 0 if pre-implementation period or 45-65 years-old; else, if postimplementation period, 1 if 66,2 if $67, \ldots 19$ if 84$)$. $\beta_{7}$ represents the difference before and after program implementation in the trajectory of the outcome with increasing age among 65-84-year-olds. 
medRxiv preprint doi: https://doi.org/10.1101/2021.06.30.21259491; this version posted July 5, 2021. The copyright holder for this preprint (which was not certified by peer review) is the author/funder, who has granted medRxiv a license to display the preprint in perpetuity.

This article is a US Government work. It is not subject to copyright under 17 USC 105 and is also made available for use under a CCO license.

$\log (N)$ : offset term, i.e., the log of the number of NYC residents by single year of age for 2019 [24]. 
medRxiv preprint doi: https://doi.org/10.1101/2021.06.30.21259491; this version posted July 5, 2021. The copyright holder for this preprint (which was not certified by peer review) is the author/funder, who has granted medRxiv a license to display the preprint in perpetuity.

This article is a US Government work. It is not subject to copyright under 17 USC 105 and is also made available for use under a CCO license.

Appendix B. Analytic dataset for primary analysis for hospitalizations using the regression discontinuity design.

\begin{tabular}{|c|c|c|c|c|c|c|c|c|c|}
\hline$Y_{y}$ & $A$ & $\mathrm{X}_{y}$ & $A X_{y}$ & $Z$ & $Z A$ & $Z X_{y}$ & $Z X_{y} A$ & $N$ & $\log (N)$ \\
\hline 161 & 0 & 0 & 0 & 0 & 0 & 0 & 0 & 99944 & 11.51237 \\
\hline 167 & 0 & 0 & 0 & 1 & 0 & 0 & 0 & 99944 & 11.51237 \\
\hline 151 & 1 & 0 & 0 & 0 & 0 & 0 & 0 & 98832 & 11.50118 \\
\hline 158 & 1 & 0 & 0 & 1 & 1 & 0 & 0 & 98832 & 11.50118 \\
\hline 161 & 2 & 0 & 0 & 0 & 0 & 0 & 0 & 100707 & 11.51997 \\
\hline 166 & 2 & 0 & 0 & 1 & 2 & 0 & 0 & 100707 & 11.51997 \\
\hline 193 & 3 & 0 & 0 & 0 & 0 & 0 & 0 & 105129 & 11.56294 \\
\hline 166 & 3 & 0 & 0 & 1 & 3 & 0 & 0 & 105129 & 11.56294 \\
\hline 193 & 4 & 0 & 0 & 0 & 0 & 0 & 0 & 110124 & 11.60936 \\
\hline 183 & 4 & 0 & 0 & 1 & 4 & 0 & 0 & 110124 & 11.60936 \\
\hline 198 & 5 & 0 & 0 & 0 & 0 & 0 & 0 & 102839 & 11.54092 \\
\hline 203 & 5 & 0 & 0 & 1 & 5 & 0 & 0 & 102839 & 11.54092 \\
\hline 222 & 6 & 0 & 0 & 0 & 0 & 0 & 0 & 101081 & 11.52368 \\
\hline 202 & 6 & 0 & 0 & 1 & 6 & 0 & 0 & 101081 & 11.52368 \\
\hline 239 & 7 & 0 & 0 & 0 & 0 & 0 & 0 & 99617 & 11.50909 \\
\hline 237 & 7 & 0 & 0 & 1 & 7 & 0 & 0 & 99617 & 11.50909 \\
\hline 284 & 8 & 0 & 0 & 0 & 0 & 0 & 0 & 102045 & 11.53317 \\
\hline 204 & 8 & 0 & 0 & 1 & 8 & 0 & 0 & 102045 & 11.53317 \\
\hline 245 & 9 & 0 & 0 & 0 & 0 & 0 & 0 & 107769 & 11.58775 \\
\hline 242 & 9 & 0 & 0 & 1 & 9 & 0 & 0 & 107769 & 11.58775 \\
\hline 281 & 10 & 0 & 0 & 0 & 0 & 0 & 0 & 106942 & 11.58004 \\
\hline 264 & 10 & 0 & 0 & 1 & 10 & 0 & 0 & 106942 & 11.58004 \\
\hline 314 & 11 & 0 & 0 & 0 & 0 & 0 & 0 & 104869 & 11.56047 \\
\hline 270 & 11 & 0 & 0 & 1 & 11 & 0 & 0 & 104869 & 11.56047 \\
\hline 328 & 12 & 0 & 0 & 0 & 0 & 0 & 0 & 101226 & 11.52511 \\
\hline 310 & 12 & 0 & 0 & 1 & 12 & 0 & 0 & 101226 & 11.52511 \\
\hline 345 & 13 & 0 & 0 & 0 & 0 & 0 & 0 & 100984 & 11.52272 \\
\hline 298 & 13 & 0 & 0 & 1 & 13 & 0 & 0 & 100984 & 11.52272 \\
\hline 325 & 14 & 0 & 0 & 0 & 0 & 0 & 0 & 105766 & 11.56898 \\
\hline 259 & 14 & 0 & 0 & 1 & 14 & 0 & 0 & 105766 & 11.56898 \\
\hline 336 & 15 & 0 & 0 & 0 & 0 & 0 & 0 & 99518 & 11.50809 \\
\hline 318 & 15 & 0 & 0 & 1 & 15 & 0 & 0 & 99518 & 11.50809 \\
\hline 399 & 16 & 0 & 0 & 0 & 0 & 0 & 0 & 97476 & 11.48736 \\
\hline 339 & 16 & 0 & 0 & 1 & 16 & 0 & 0 & 97476 & 11.48736 \\
\hline 420 & 17 & 0 & 0 & 0 & 0 & 0 & 0 & 96383 & 11.47609 \\
\hline 317 & 17 & 0 & 0 & 1 & 17 & 0 & 0 & 96383 & 11.47609 \\
\hline 385 & 18 & 0 & 0 & 0 & 0 & 0 & 0 & 92818 & 11.438 \\
\hline 336 & 18 & 0 & 0 & 1 & 18 & 0 & 0 & 92818 & 11.4384 \\
\hline 383 & 19 & 0 & 0 & 0 & 0 & 0 & 0 & 92945 & 11.43976 \\
\hline 338 & 19 & 0 & 0 & 1 & 19 & 0 & 0 & 92945 & 11.439 \\
\hline
\end{tabular}


medRxiv preprint doi: https://doi.org/10.1101/2021.06.30.21259491; this version posted July 5, 2021. The copyright holder for this preprint (which was not certified by peer review) is the author/funder, who has granted medRxiv a license to display the preprint in perpetuity.

This article is a US Government work. It is not subject to copyright under 17 USC 105 and is also made available for use under a CCO license.

\begin{tabular}{|c|c|c|c|c|c|c|c|c|c|}
\hline 373 & 20 & 1 & 0 & 0 & 0 & 0 & 0 & 86105 & 11.36332 \\
\hline 268 & 20 & 1 & 0 & 1 & 20 & 1 & 0 & 86105 & 11.36332 \\
\hline 399 & 21 & 1 & 1 & 0 & 0 & 0 & 0 & 81196 & 11.30462 \\
\hline 276 & 21 & 1 & 1 & 1 & 21 & 1 & 1 & 81196 & 11.30462 \\
\hline 377 & 22 & 1 & 2 & 0 & 0 & 0 & 0 & 78192 & 11.26692 \\
\hline 286 & 22 & 1 & 2 & 1 & 22 & 1 & 2 & 78192 & 11.26692 \\
\hline 438 & 23 & 1 & 3 & 0 & 0 & 0 & 0 & 76195 & 11.24105 \\
\hline 287 & 23 & 1 & 3 & 1 & 23 & 1 & 3 & 76195 & 11.24105 \\
\hline 406 & 24 & 1 & 4 & 0 & 0 & 0 & 0 & 77376 & 11.25643 \\
\hline 279 & 24 & 1 & 4 & 1 & 24 & 1 & 4 & 77376 & 11.25643 \\
\hline 437 & 25 & 1 & 5 & 0 & 0 & 0 & 0 & 72111 & 11.18596 \\
\hline 264 & 25 & 1 & 5 & 1 & 25 & 1 & 5 & 72111 & 11.18596 \\
\hline 424 & 26 & 1 & 6 & 0 & 0 & 0 & 0 & 69942 & 11.15542 \\
\hline 286 & 26 & 1 & 6 & 1 & 26 & 1 & 6 & 69942 & 11.15542 \\
\hline 446 & 27 & 1 & 7 & 0 & 0 & 0 & 0 & 68718 & 11.13777 \\
\hline 253 & 27 & 1 & 7 & 1 & 27 & 1 & 7 & 68718 & 11.13777 \\
\hline 435 & 28 & 1 & 8 & 0 & 0 & 0 & 0 & 55176 & 10.91828 \\
\hline 296 & 28 & 1 & 8 & 1 & 28 & 1 & 8 & 55176 & 10.91828 \\
\hline 419 & 29 & 1 & 9 & 0 & 0 & 0 & 0 & 53784 & 10.89273 \\
\hline 271 & 29 & 1 & 9 & 1 & 29 & 1 & 9 & 53784 & 10.89273 \\
\hline 382 & 30 & 1 & 10 & 0 & 0 & 0 & 0 & 49135 & 10.80233 \\
\hline 210 & 30 & 1 & 10 & 1 & 30 & 1 & 10 & 49135 & 10.80233 \\
\hline 327 & 31 & 1 & 11 & 0 & 0 & 0 & 0 & 48913 & 10.7978 \\
\hline 240 & 31 & 1 & 11 & 1 & 31 & 1 & 11 & 48913 & 10.7978 \\
\hline 331 & 32 & 1 & 12 & 0 & 0 & 0 & 0 & 44228 & 10.69711 \\
\hline 194 & 32 & 1 & 12 & 1 & 32 & 1 & 12 & 44228 & 10.69711 \\
\hline 364 & 33 & 1 & 13 & 0 & 0 & 0 & 0 & 40917 & 10.6193 \\
\hline 202 & 33 & 1 & 13 & 1 & 33 & 1 & 13 & 40917 & 10.6193 \\
\hline 338 & 34 & 1 & 14 & 0 & 0 & 0 & 0 & 40413 & 10.60691 \\
\hline 180 & 34 & 1 & 14 & 1 & 34 & 1 & 14 & 40413 & 10.60691 \\
\hline 341 & 35 & 1 & 15 & 0 & 0 & 0 & 0 & 36667 & 10.50963 \\
\hline 179 & 35 & 1 & 15 & 1 & 35 & 1 & 15 & 36667 & 10.50963 \\
\hline 327 & 36 & 1 & 16 & 0 & 0 & 0 & 0 & 34693 & 10.45429 \\
\hline 220 & 36 & 1 & 16 & 1 & 36 & 1 & 16 & 34693 & 10.45429 \\
\hline 349 & 37 & 1 & 17 & 0 & 0 & 0 & 0 & 31358 & 10.35322 \\
\hline 193 & 37 & 1 & 17 & 1 & 37 & 1 & 17 & 31358 & 10.35322 \\
\hline 349 & 38 & 1 & 18 & 0 & 0 & 0 & 0 & 29327 & 10.28626 \\
\hline 200 & 38 & 1 & 18 & 1 & 38 & 1 & 18 & 29327 & 10.28626 \\
\hline 295 & 39 & 1 & 19 & 0 & 0 & 0 & 0 & 27021 & 10.20437 \\
\hline 196 & 39 & 1 & 19 & 1 & 39 & 1 & 19 & 27021 & 10.20437 \\
\hline
\end{tabular}

